\title{
KORELASI PENGUASAAN TIK GURU DENGAN KEMAMPUAN TIK SISWA
}

\author{
Widaryanto $^{1}$, Wahyu Bagja Sulfemi ${ }^{2}$ \\ STKIP Muhammadiyah Bogor \\ Korespondensi: Administrasi Pendidikan \\ STKIP Muhammadiyah Bogor: Jalan Raya Leuwiliang No. 106 Bogor 16640 \\ surel: wahyubagja@gmail.com
}

\begin{abstract}
ABSTRAK
Penelitian ini untuk mengetahui hubungan antara persepsi siswa tentang penguasaan TIK guru terhadap kemampuan TIK siswa di SMK Giri taruna Kecamatan.Jasingan Kabupaten.Bogor, Penelitian ini adalah penelitian korelasi, yang di analisis dengan korelasi product moment, sebelum di analilis perlu adanya pengujian untuk sebagai persyaratan analisis data yaitu dengan uji validitas, uji reliabilitas dan uji normalitas, dari ketiga uji tersebut instrument dinyatakan valid, reliabel, kemudian di lanjutkan dengan penelitian yang hasil uji kenormalan datanya menunjukan normal.Setelah melakukan uji tersebut, data di olah dengan menggunakan korelasi yang hasilnya terdapat korelasi yang positif dengan nilai $r_{x y}=$ 0,272777549 dan $r_{\text {tabel }} 0,265613918$ kemudian untuk mengetahui persentase hubungan antara persepsi siswa dengan kemampuan TIK siswa mengunakan koefisien determinasi dengan perolehan angka persentase sebesar 7,45\%, kemudian uji signifikasi mengunakan " $\mathrm{t}$ " diperoleh $t_{\text {hitung }}=2,06440860409$ dan $t_{\text {tabel }}=2,005745949$ maka data tersebut signifikan. Dari data di atas menujukan bahwa hubungan persepsi siwa tentang penguasaan TIK guru terhadap kemampuan TIK siswa sebesar 7,45\% dengan kriteria rendah dan sisanya sebesar 92,55\% dipengaruhi oleh faktor lain.
\end{abstract}

Kata Kunci : persepsi siswa, penguasaan tik guru, kemampuan tik siswa

\begin{abstract}
This study was to determine the relationship between students' perceptions of mastery of teacher ICT on the ability of ICT students in Giri Taruna Subdistrict, Jasingan District, Bogor, this study was a correlation study, which was analyzed by product moment correlation, before analysis, testing was needed as a requirement data analysis is by validity test, reliability test and normality test, from the three tests the instrument was declared valid, reliable, then continued with research that the normality test results showed normal data. After doing the test, the data is processed using correlations whose results are positive correlation with the value of $r_{-} x y=0.272777549$ and $r_{-}$tabel 0.265613918 then to find out the percentage relationship between student perceptions and ICT abilities students use the coefficient of determination with the acquisition of a percentage number of $7.45 \%$, then test significance using " $t$ " obtained $t_{-}$count $=2,06440860409$ and $t_{-}($table $)=2.005745949$ then the data is significant. From the data above shows that the relationship of student perceptions of mastery of ICT teachers to students' ICT skills is $7.45 \%$ with low criteria and the remaining $92.55 \%$ is influenced by other factors.
\end{abstract}

Keywords: student perception, mastery of teacher's teacher, students' ability to tick 


\section{PENDAHULUAN}

Guru merupakan komponen paling menentukan dalam sistem pendidikan secara keseluruhan, yang harus mendapat perhatian sentral, pertama, dan utama. Figur yang satu ini akan senantiasa menjadi sorotan strategis ketika berbicara masalah pendidikan, karena guru selalu terkait dengan komponen manapun dalam sistem pendidikan. Dan guru memegang peran utama dalam pembangunan pendidikan. Khususnya yang diselenggarakan secara formal di sekolah. Guru juga sangat menentukan keberhasilan peserta didik, terutama dalam kaitannya dengan proses belajar mengajar.

Untuk memenuhi tuntutan di era globalisasi seperti sekarang ini seorang guru harus mampu beradaptasi dengan pembelajaran, perkembangan dan perubahan masyarakat, seperti yang di kemukakan oleh: Masyarakat dapat di bagi atas masyarakat (Agricultural), masyarakat (Industrial), dan masyarakat pembelajar (learning society) (Dedi Koswara, 2008 :133). ketiga masyarakat tersebut dalam memenuhi kebutuhan hidupnya di era sekarang ini tidak terlepas dari teknologi informasi dan komunikasi.

Dalam penelitian ini, peneliti menitik beratkan pada masyarakat pembelajar sebagai latarbelakang dari sebuah penelitian yang akan di laksanakan, pada era learning society, yang ditandai dengan kemajuan pesat teknologi informasi (internet,e-mail, website, animasi, VCD/DVD, berbagai software pendidikan) dan infrastruktur tekomunikasi (telekomfrece, e-learning, m-learning), oleh sebab itu seorang guru harus mengusai teknologi informasi serta infrastruktur telekomunikasi dalam proses pembelajaran, untuk mewujudkan penguasaan TIK pada seluruh guru memang tidak mudah tentunya dibutuhkan upaya-upaya yang terus dilakukan untuk meningkatkan kualitas guru terutama di dalam penguasaan teknolgi informasi dan komunikasi, dilihat dari kebutuhannya sangatlah penting seorang guru untuk dapat menguasai teknologi informasi dan komunikasi terutama di bidang pembelajaran agar mampu menghasilkan lulusan-lulusan pendidikan yang terampil dan memiliki kemampuan di bidang teknologi informasi dan komunikasi, yang harapannya adalah peserta didik yang telah lulus dapat bersaing di masyarakat yang sering disebut juga dengan masyarakat dunia di era teknologi sekarang ini. Akan tetapi fenomena siswa SMK Giri Taruna, Kecamatan. Jasinga, Kabupaten. Bogor, berdasarkan dari hasil pengamatan penulis, ternyata masih banyak siswa yang mendapatkan hasil nilai yang kurang baik dalam mata pelajaran KKPI yang berhubungan dengan teknologi informasi dan komunikasi hal tersebut ditunjukan dengan minat belajar yang kurang maksimal, tingkat keaktifan yang rendah, dan kurangnya aspirasi belajar dikelas, sementara itu kondisi SMK Giri Taruna, Kecamatan.Jasinga, Kabupaten.Bogor. adalah sekolah yang dapat dikatakan dengan sekolah yang memiliki fasilitas teknologi informasi dan komunikasi yang baik dan kompetensi guru yang melaksanakan pembelajaran adalah guru yang berkompeten dalam bidangnya, berdasarkan hal tersebut kemampuan TIK siswa mungkin disebabkan oleh persepsi siswa tentang penguasaan TIK gurunya yang kurang baik sehingga hal tersebut juga berhubungan dengan kemampuan TIK siswanya.

Istilah teknologi informasi dan komunikasi lahir pada abab keduapuluh yang diawali dengan terbentuknya masyarakat informasi istilah teknologi informasi yang menggunakan istilah TK ( Teknologi komunikasi ) yang dikenal lebih dahulu. Kita melihat ada teknologi komunikasi yang berfungsi sebagai penyaluran informasi, ada juga teknologi informasi yang berfungsi sebagai penyimpan dan mengolah informasi. Fungsi yang terakhir inilah yang menyebabkan orang menyebutnya teknologi komunikasi sebagai teknologi informasi. Teknologi informasi adalah pemprosesan, pengolahan, dan penyebaran sata oleh kombinasi computer dan telekomunikasi. Teknologi informasi lebih kepada pengerjaan terhadap data. TI menitik beratkan perhatiannya kepada bagaimana data diolah dan diproses dengan komputer dan telekomunikasi. (Udin Syaefudin Sa'ud, 2011:183)

Dalam konteks yang lebih luas, teknologi informasi dan komunikasi merangkum semua aspek yang berhubungan dengan mesin computer dan komunikasi dan teknik yang digunakan untuk menangkap, mengumpulkan, menyimpan, mamanipulasi menghantar dan mempersembahkan suatu bentuk informasi yang besar. komputer yang mengendalikan semua bentuk idea dan informasi memainkan peranan yang sangat penting. Pada awalnya teknologi informasi diartikan sebagai perangkat keras dan lunak untuk melaksanakan satu atau sejumlah tugas pemprosesan data namun dalam perkembangannya terdapat respon yang lebih luas, diman teknologi informasi juga mencakup teknik komunikasi sebagai srana untuk mengirim informasi dalam bentuk elektronik, software pemproses transaksi perangkat lunak untuk lembar kerja, peralatan komunikasi serta jarinagan termasuk pada wilayah teknologi informasi, teknologi informasi bukan hanya sebagai sarana fisik namun dapat berfungsi sebagai yang meneruskan nilai-nilai bagi para pemakainya, terdapat beberapa pandangan yang mengarah kepada devinisi e-learning

Pada akhirnya elektronik learning dapat didevinisikan sebagai upaya menghubungkan pembelajar ( siswa dengan sumber belajar ( data base, pakar/guru, perpustakaan) yang secara fisik terpisah atau bahkan berjauhan, intraktivitas dalam hubungan tersebut dapat dilakukan secara langsung (synchronous) maupun tidak langsung (asynchronous) (Udin Syaefudin Sa'ud, 2011: 183-184) 
Pengertian teknologi informasi dan komunikasi menurut para ahli adalah sebagai berikut, teknologi informasi dan komunikasi adalah kebutuhan manusia didalam mengambil dan memindahkan , mengolah dan memproses informasi dalam konteks sosial yang menguntungkan diri sendiri dan masyarakat secara keseluruhan. Sementara itu pendapat yang lain yaitu sebagai berikut, teknologi informasi dan komunikasi adalah sebuah media atau alat bantu yang digunakan untuk transfer data baik itu untuk memperoleh suatu data/informasi maupun memberikan informasi kepada orang lain serta dapat digunakan untuk alat berkomunikasi baik satu arah ataupun dua arah. (Bambang Tri R Nugroho, 2008: 1) Teknologi informasi dan komunikasi adalah suatu padanan yang tidak terpisahkan yang mengandung pengertian luas tentang segala kegiatan yang terkait dengan pemrosesan, manipulasi, pengelolaan, dan transfer/pemindahan informasi antar media (http://www.artikata.com/arti-369095-penguasaan.html. Donwload Tanggal 7 November 2014)

Penggunaan teknologi dalam pendidikan dan pembelajaran dimaksudkan untuk memudahkan atau mengefektifkan kegiatan pembelajaran. Dalam hal ini guru dituntut untuk memiliki kemampuan mengunakan dan mempersiapkan materi pembelajaran dalam suatu sistem jaringan komputer yang dapat diakses oleh peseta didik, oleh karena itu seyogyanya guru dan calon guru dibekali dengan berbagi kompetensi yang berkaitan dengan penggunaan teknologi nformasi dan komunikasi sebagai teknologi pembelajaran.

Perubahan perinsip belajar berbasis computer memberikan dampak pada profesionalisme guru, sehinnga harus menambah pemahaman dan kompetensi baru untuk memfasilitasi pembelajaran. Demgan sistem komputer belajar tidak terbatas pada empat dinding kelas, tetapi dapat menjelajah ke dunia lain , terutama melalui internet. Dalam hal ini guru dituntut untuk memiliki kemampuan mengorganisir, menganalisis dan memilih informasi yang paling tepat dan berkaitan langsung dengan langsung dengan pembentukan kompetensi peserta didik serta tujuan pembelajaran. Dengan demikian penguasaan TIK guru dalam pembelajaran menjadi sangat penting. (Mulyasa, $2009: 107-108$ )

Sebagai dasar untuk memanfaatkan teknologi informasi dan komunikasi sebagai media pembelajaran dalam seting sekolah, ada beberapa hal yang perlu mendapat perhatian dan penanganan yang seharusnya agar penyelenggaraan pemanfaatan teknologi informasi dan komunikasi untuk pembelajaran yang bisa berhasil yaitu:

1) Faktor lingkungan, yang meliputi instuisi penyelenggara pendidikan dan masyarakat.

2) Siswa dan peserta didik meliputi usia, latar belakang, budaya, penguasaan bahasa dan berbagai gaya belajarnya.

3) Guru atau pendidik meliputi latar belakang, usia, gaya mengajar, pengalaman dan personalitinya.

4) Faktor teknologi meliputi computer, perangkat lunak, jarinagan, koneksi ke internet dan berbagai kemampuan yang dibutuhkan berkaitan dengan penerapan internet dilingkungan sekolah.

Penggunaan teknologi informasi dan komunikasi berdasarkan pedagogi, intergensi, pennggunaan TIK dalam mata pelajaran, administrasi kelas, dan kolaborasi pengajaran serta pembelajaran berbasis online, yaitu sebagai berikut: (1)Integrasi TIK dalam pengajaran untuk mata pelajaran yang spesifik, seperti sains, teknologi, matematika, ilmu sosial, bahasa, seni dan sastra. Penggunaan peralatan komunikasi online, seperti e-mail untuk mengambil bagian dalam proyek kolaborasi online untuk menjalankan penelitian. (2) Menghubungkan sekolah dalam masyarakat. (3) nPeran TIK guru, maka pengintegrasian TIK dalam proses pembelajaran harus memungkinkan dirinya (4) Peran TIK bagi siswa, pengintegrasian TIK dalam proses pembelajaran harus memungkinkan siswa.

Pengajaran terhadap siswa tetang bagaiman menggunakan sistem komputer (berdasarkan kebutuhan untuk mengetahui) sehingga mereka dapat menggunakan sistem secara cakap untuk mengetahui tugastugas mereka. Pengalaman - pengalaman pertama dalam menggunakan komputer seharusnya menyenangkan dan merangsang. Geme - game pendidikan dan paket-paket pembelajran yang didukung oleh computer yang bagus, dan software grafik yang sederhana bisa memberikan kepada siswa sebuah pengantar yang bagus kepada penggunaan komputer.

Guru adalah pendidik professional yang mempuanyai tugas, dan fungsi, dan peran penting dalam kehidupan bangsa, guru yang profesional daiharapkan mampu berpartisipasi dalam pembangunan nasional untuk mewujudkan insane Indonesia yang bertakwa kepada tuhan yang maha Esa, unggul dalam ilmu pengetahuan dan teknologi, memiliki jiwa estetis, etis, berbudi pekerti luhur, dan berkepribadian.( Dermawati, 2013:1)

Guru adalah salah satu komponen manuasiawi dalam proses belajar mengajar, yang ikut berperan dalam usaha pembentukan sumber daya manusia yang potensisal dibidang pembangunan. Oleh karana itu, guru merupakan salah satu unsure di bidang pendidikan harus berperan serta secara aktif dan menempatkan kedudukannya sebagai tenaga profesional, sesuai dengan tuntutan masyarakat yang semakin berkembang. Dalam arti khusus dapat dikatakan bahwa pada setiap diri guru itu terletak pada 
tanggungjawab untuk membawa sisiwanya pada suatu kedewasaan atau taraf kematangan tertentu. Dalam rangka ini guru tidak semata-mata sebagai pengajar yang melakukan transfer of knowledge, teratpi juga sebagai pendidik yang melakukan transfer of values dan sekaligus sebagai pembimbing yang memberikan pengarahan dan menuntun siswa dalam belajar. Berkaitan dengan itu guru memiliki peranan yang unik dan sangat kompleks di dalam proses belajar mengajar dalam usaha untuk mengantarkan siswa /anak didik ketaraf yang dicita-citakan oleh karna itu setiap rencana kegiatan guru harus dapat dudukan dan di benarkan semata-mata demi kepentingan anak didik, sesuai dengan profesi dan tanggung jawabnya. (Sardiman, 2011: 125)

Selanjutnya untuk mewujudkan hal tersebut ada tugas dan syarat yang harus dimiliki guru dan melakukan pembelajaran dan mendidik siswanya. Tugas guru melakukan : (1) Perencanaan Program Kegiatan (2) Pelaksanaan Kegiatan Pembelajaran (3)Penggunaan Media dan Sumber Belajar (4) Penggunaan metode pembelejaran (5) Evaluasi

Dari berbagai persyaratan yang telah didkemukakan menunjukan bahwa guru menempati bagian tersendiri dengan berbagai ciri kekhususanya, apalagi bila dilihat dari tugas keprofesionalannya, sesuai dengan keprofesiannya, maka sifat dan persyaratan tersebut secara garis besar dapat diklasifikasikan dalam spectrum yang lebih luas guru harus: (1). Memiliki kemampuan profesional. (2). Memiliki kompetensi pedagogic (3).Memiliki kompetensi social (4).Memiliki kompetensi kepribadian.

Penguasan TIK guru adalah pemahaman atau kesanggupan untuk menggunakan (pengetahuan, kepandaian) sebuah media atau alat bantu yang digunakan untuk transfer data baik itu untuk memperoleh suatu data / informasi maupun memberikan informasi kepada orang lain serta dapat digunakan untuk alat berkomunikasi baik satu arah ataupun dua arah oleh seseorang atau sekelompok yang berprofesi pengelola kegiatan pembelajaran dan seperangkat peranan lainnya yang memungkinkan berlangsungnya kegiatan belajar yang efektif.

\section{METODOLOGI PENELITIAN}

Pendekatan yang digunakan dalam penelitian ini adalah pendekatan kuantitatif yaitu penelitian yang terdiri dari kejelasan tujuan pendekatan, sampel sumber data dan subjek yang sudah ada dan rinci sejak awal. Sedangkan rancangan penelitian menggunakan metode deskriptif kolerational, yang sesuai dengan tujuan dari penelitian yaitu melihat hubungan persepsi siswa tentang penguasaan TIK guru terhadap kemampuan TIK siswa. Data yang akan dihasilkan adalah data kuantitatif yaitu berupa angka angka yang akan dianalisa dan hasilnya dijelaskan secara deskriptif.

Populasi adalah siswa dan siswi kelas XII Jurusan Administrasi Perkantoran SMK Giri Taruna Kec.Jasingan, Kabupaten Bogor, yang berjumlah 177 siswa dengan jumlah sampel 53.

Teknik pengumpulan data dalam hal ini, peneliti mengguanakan beberapa teknik dalam mengumpulkan informasi dan data, baik sebagai informasi dan data yang akan di olah dalam pelaksanaan penelitian, maupun informasi dan data pendukung dalam proses penelitian, dalam hal ini peneliti menggunakan beberapa teknik, yaitu: Angket (kuesioner) dan Tes

Penelitian ini menggunakan angket (kuesioner) untuk memperoleh data tentang persepsi siswa tentang Penguasaan TIK guru. Angket ini berisi butir-butir pertanyaan untuk memberi tanggapan oleh siswa objek penelitian. Angket dalam penelitian ini dibuat dalam skala likert digunakan untuk mengukur sikap, pendapat, dan persepsi seseorang atau kelompok orang tentang fenomena sosial dengan skala likert maka variabel yang akan diukur dijabarkan menjadi indikator variabel kemudian indikator tersebut dijadikan sebagai titik tolak untuk menyusun item-item instrument yang dapat berupa pertanyaan. Masing-masing variabel menyediakan 4 (empat) jawaban alternatif. Untuk persepsi siswa tentang penguasaan TIK guru, data diperoleh diperoleh dengan instrumen angket yakni dengan memilih jawaban, Sangat Stuju (SS), Setuju (S), Ragu-Ragu (R), dan Tidak setuju(TS), Sangat tidak setuju (STS) .

Sementara itu dalam memperoleh data variabel $Y$ yaitu kemampuan TIK siswa peneliti menggunakan tes untuk mengukur kemampuan siswa dengan menggunakan soal pilihan ganda yang memilih satu jawaban pilihan yang dianggapnya benar dengan alternatif jawaban sebagai berikut (a, b, c, $\mathrm{d}$, e,). Selanjutnya dibawah ini adalah kisi-kisi instrument penelitian dari variabel $\mathrm{X}$ yaitu persepsi siswa tentang penguasaan TIK guru dan variabel Y yaitu kemampuan TIK siswa.

\section{HASILPENELITIAN DAN PEMBAHASAN}

Untuk memperoleh data persepsi siswa tentang penguasaan TIK guru peneliti menggunakan angket dengan butir angket sebanyak 20 yang di ujikan pada siswa kelas dua belas SMK Giri Taruna dengan jumlah responden atau sampel sebanyak 53 siswa, Setelah memperoleh nilai dari variabel $\mathrm{x}$ selanjutnya adalah mengklasifikasikan data sesuai dengan skor agar lebih mempermudah peneliti dalam menganalisis data. 
Berdasarkan data pada tabel di dapat hasil nilai memiliki presentase rata-rata $74 \%$, langkah selanjutnya adalah mencari rata-rata dan kualitas variabel X ( Persepsi siswa tentang penguasaan TIK guru ) Dari data komulatif variabel X ( Persepsi siswa tentang penguasaan TIk guru) dari 53 responden didapat data sebagai berikut yaitu: Nilai terendah sebesar 62, Nilai tertinggi 87, Rentang nilai sebesar 22, Modus sebesar 78,2, Median sebesar 75,3, Mean sebesar 74,6.

Berdasarkan data di atas dapat dilihat bahwa banyaknya penilaian persepsi siswa tentang penguasaan TIK guru berkisar anatara 78-81, untuk mengetahui kecendrungan penilaian persepsi siswa tentang penguasaan TIK guru secara keseluruhan dapat diketahui melalui perhitungan persentase frekuensi dengan rumus perhitungan frekuensi

Hasil perhitungan menunjukan bahwa penilaian persepsi siswa tentang penguasaan TIK guru sangat tinggi sebesar $1,88 \%$, kemudian criteria tinggi sebesar 49,05\% dan criteria sedang sebesar 49, 05 $\%$. Untuk memeperoleh data kemampuan TIK siswa peneliti menggunakan tes dalam bentuk soal pilihan ganda sebanyak 20 butir soal yang di ujikan kepada 53 responden, siswa kelas dua belas SMK Giri Taruna.

Setelah memperoleh nilai dari variabel Y, selanjutnya adalah mengklasifikasikan data sesuai dengan skor agar lebih mempermudah peneliti dalam menganalisis data selanjutnya.

Berdasarkan data pada tabel diatas dapat disimpulkan bahwa nilai dari jawaban responden memiliki presentase rata-rata $66 \%$, langkah selanjutnya adalah mencari rata-rata dan kualitas variabel Y ( Kemampuan TIK siswa ) Dari data komulatif variabel X ( Persepsi siswa tentang penguasaan TIk guru) dari 53 responden didapat kesimpulan data sebagai berikut yaitu: Nilai terendah sebesar 50, Nilai tertinggi 90, Rentang nilai sebesar 46, Modus sebesar 54,2, Median sebesar 61,9, Mean sebesar 65,1.

Berdasarkan data di atas dapat dilihat bahwa banyaknya penilaian persepsi siswa tentang kemampuan TIK siswa berkisar anatara 50-56, untuk mengetahui kecendrungan penilaian persepsi siswa tentang kemampuan TIK siswa secara keseluruhan dapat diketahui melalui perhitungan persentase frekuensi. Hasil perhitungan menunjukan bahwa penilaian persepsi siswa tentang penguasaan TIK guru sangat tinggi sebesar 9,43\%, kemudian kriteria tinggi sebesar 16,98 \% kriteria sedang sebesar 45, $28 \%$, dan kriteria rendah sebesar $28,30 \%$.

Interpretasi data hasil penelitian dengan judul hubungan persepsi siswa tentang penguasaan TIK guru terhadap kemampuan TIK siswa studi analisis pada kelas XII SMK Giri Taruna, Kec.Jasingan, Kab.Bogor, Untuk jumlah responden sebanyak 53 siswa dengan jumlah 40 instrumen, masing-masing 20 butir pernyataan sikap yang bentuknya angket untuk memperoleh data X yaitu ( Persepsi siswa tentang penguasaan TIK guru), dan 20 butir soal untuk memperoleh data Y yaitu (kemampuan TIK siswa ), Berikut ini adalah interprestasi data variabel $\mathrm{X}$ (Persepsi siswa tentang penguasaan TIK guru) dan variabel Y ( kemampuan TIK siswa.

Setelah diketahui antara kedua variabel diatas melalui statistik person product moment, maka selanjutnya dilakukan korelasi person product moment dengan hasil sebagai 0,27277754.

Selanjutnya untuk menyatakan besar kecilnya sumbangan presentasi variabel $\mathrm{X}$ terhadap variabel Y dapat ditentukan dengan rumus koefisien determinan didapat hasil sebagai berikut:= 7,4475912384 dibulatkan menjadi $7,45 \%$

Artinya hubungan persepsi siswa tentang penguasaan tik guru terhadap kemampuan TIK siswa Sebesar 7,45\% dan sisanya sebanyak $92,55 \%$ dipengaruhi oleh faktor-faktor lain

Interprestasi secara sederhana dari perhitungan di atas ternyata angka korelasi antara variabel $\mathrm{X}$ dan variabel Y tidak bertanda negatif berarti diantara variabel tersebut terdapat korelasi positif ( korelasi yang berjalan searah). Interprestasi dengan menggunakan tabel nilai" r" $: \mathrm{df}=\mathrm{N}-\mathrm{nr}=53-2=51$ pada taraf signifikasi $5 \%$ diperoleh $r_{\text {tabel }}=\underline{0,265613918}$ sementara diperoleh $r_{r x y}=\underline{0,272777549}$. Selanjutnya dapat disimpulkan bahwa bahwa $r_{r x y}$ lebih besar dari pada $r_{\text {tabel }}(0,272777549>265613918) . r_{x y}>r_{\text {tabel }}=$ tolak Ho. 0,2727775490 > $265613918=$ tolak Ho. Dalam penelitian ini terdapat hubungan yang signifikan antara persepsi siswa tentang penguasaan TIK guru terhadap kemampuan TIK siswa.

Untuk menguji keberartiannya sebelum ditafsirkan, maka terlebih dahulu diujikan uji t pada taraf signifikan, di dapat hasil sebagai berikut $=2,06440860409$. Pada taraf signifikasi 0,05 dengan $\mathrm{dk}=\mathrm{N}-2=$ $53-2=51$ adalah 2.005745949, dari hasil perhitungan diperoleh $t_{\text {hitung }} 2,06440860409$ sedangkan $\mathrm{t}_{\text {tabel }} 2.005745949$ yang berarti $\mathrm{t}_{\text {hitung }}>\mathrm{t}_{\text {tabel }}$ maka koefisien korelasi adalah signifikan dengan demikian terdapat hubungan positif antara persepsi siswa tentang penguasaan TIK guru terhadap kemampuan TIK siswa kelas XII Administrasi perkantoran SMK Giri Taruna Kec.Jasinga, Kab. Bogor.

Kesimpulan yang dapat kita tarik bahwa tinggi rendahnya persepsi siswa tentang penguasaan TIK guru memiliki hubungan dengan kemampuan TIK siswa, dibuktikan dengan data nilai , persepsi siswa tentang penguasaan TIK guru dari 53 responden kelas XII SMK Giri Taruna yang berjumlah 3945 dengan 
nilai rata-rata 74, berarti dapat dikategorikan baik atas persepsi mereka terhadap gurunya. Dan data selanjutnya adalah data tentang kemampuan TIK siswa yang memilki jumlah nilai 3480 dengan nilai ratarata 66 yang dapat dikategorikan baik.

Dari pengaujuan hipotesis sebelumnya terdapat dua pengajuan yaitu:

$\mathrm{H}_{1} \quad$ :Terdapat hubungan signifikan antara persepsi siswa tentang penguasaan TIK guru tehadap kemampuant TIK siswa.

Ho :Tidak terdapat hubungan signifikan antara persepsi siswa tentang penguasaan TIK guru terhadapa kemampuan TIK siswa.

Dari dua pengajuan diatas dapat disimpulkan bahwa pengajuan hipotesis Ho ditolak dan pengajuan Ha diterima karna data penelitian membuktikan bahwa $r_{x y}$ lebih besar dari $r_{\text {tabel }}$ dengan angka statistik sebagai brikut:

$$
\begin{array}{ll}
r_{x y} & : 0,2727775490 \\
r_{\text {tabel }} & : 0,265613918
\end{array}
$$

Maka kesimpulan dari pembuktian hipostesis ini adalah terdapat hubungan signifikan antara persepsi siswa tentang penguasaan TIK guru terhadap kemampuan TIK siswa.

Berdasarkan kriteria tingkat korelasi di atas diketahui $r_{x y}$ atau $r_{\text {hitung }}$ adalah 0,2727775490 yang berarti ada diantara 0,20 dan 0,40 maka dapat dikatakan bahwa hubungan persepsi siswa tentang penguasaan TIK guru tarhadap kemampuan TIK siswa mempunyai hubungan dalam kriteria rendah.

\section{KESIMPULAN DAN SARAN}

\section{A. Kesimpulan}

Berdasarkan penelitian yang telah dilakukan maka kesimpulan yang di ambil dari penelitian ini adalah bahwa persepsi siswa tentang penguasaan TIK guru kelas XII program keahlian administrasi perkantoran SMK Giri Taruna Kecamatan. Jasinga, Kabupaten. Bogor, memiliki hubungan yang signifikan terhadap kemampuan TIK nya, hal tersebut di buktikan dengan data statistik penelitian bahwa uji korelasional menunjukan data positif yaitu $r_{x y}$ sebasar $(0,2727775490)$ dengan perbandingan $r_{\text {tabel }}$ sebesar ( 0,265613918) lalu koefisien determinan sebesar ( 7,45\%) selanjutnya uji "t" signifikasi $t_{\text {hitung }}$ sebesar ( 2,06440860409) dengan perbandingan $t_{\text {tabel }}$ sebesar ( 2,005745949), dari data di atas maka kesimpulan akhir dari penelitian ini adalah hubungan persepsi siswa tentang penguasaan TIK guru terhadap kemampuan TIK siswa kelas XII SMK Giri Taruna, Kecamatan.Jasinga, Kabupaten.Bogor, memiliki korelasi positif dengan besaran persentase sebanyak 7,45 \% masuk dalam kriteria rendah, sementara 92,55\% lainnya, di pengaruhi oleh faktor - faktor lain.

\section{B. Saran}

Berdasarkan hasil penelitian dapat diketahui bahwa terhadap hubungan antara persepsi siswa tentang penguasaan TIK guru terhadap kemampuan TIK siswa kelas XII program Administrasi perkantoran SMK Giri Taruna Kec. Jasinga, Kab. Bogor, maka saran yang disampaikan penulis adalah:

1. Untuk siswa

a. Hendaknya siswa dapat meningkatkan kemampuan TIK sebagai ketarampilan yang nanti akan dibawa kedalam kehidupan sehari-hari baik dalam dunia kerja maupun di masyarakat.

b. Siswa daiharapakan dapat mengasah kemampuannya baik dalam pembelajaran sekolah yang diberikan oleh gurunya ataupun mengasah kemampuannya sendri seecara mandiri.

c. Siswa diharapkan memiliki motivasi lebih untuk giat belajar dalam mengembangkan kemampuan TIKnya.

d. Siswa hendaknya mampu mengapliikasikan kemampuan TIKnya untuk memenuhi kebutuhan akademiknya.

2. Untuk Guru

a. Guru diharapkan dapat memberikan kemampuan terbaiknya dalam mendidik dan memberikan pembelajaran kepada siswa.

b. Guru dapat memberikan motivasi kepada siswa agar siswa giat belajar terutama pada mata pelajaran TIK.

c. Guru dapat memberikan pemahaman tentang pentingnya penggunaan teknologi informasi dan komunikasi dalam kehidupan sehari-hari.

d. Guru diharapkan dapat mengembangkan potensi peserta didiknya di bidang teknologi informasi dan komunikasi. 
e. Guru diharapkan dapat meningkatkan kualitasnya terutama di bidang teknologi iformasi dan komunikasi.

3. Untuk Sekolah

a. Sekolah diharapkan dapat meningkatkan fasilitas pembelajaran terutama peningkatan fasilitas yang berhubungan dengan teknologi informasi dan komunikasi.

b. Sekolah di harapakan dapat menerapkan sistem ICT dalam pelayanan terhadap siswanya.

c. Sekolah diharapkan dapat memenuhi kebutuhan siswa yang berkaitan dengan TIK siswa.

d. Sekolah dapat bekerjasama dengan seluruh elemen pendidikan untuk mewujudkan sistem pembelajaran, pelayanan, berbasis TIK guna membentuk lulusan-lulusan yang siap bersaing di era teknologi informasi dan komunikasi global ini.

\section{DAFTAR PUSTAKA.}

Arikunto,Suharsimi, 2010. Prosedur Penelitian Suatu Pendekatan Praktik, Jakarta: Rineka Cipta.

Rineka Cipta

2006. Prosedur Penelitian Suatu Pendekatan Praktik, Jakarta:

Dermawati, 2013, Penilaian Angka Kredit Guru, Jakarta: Bumi Aksara

Desmita, 2012. Psikologi Perkembangan Peserta Didik, Bandung: Remaja Rosdakarya.

Imron, Ali, 2003. Manajemen Pendidikan, Malang : Universitas Negeri Malang.

Koswara, Deni, 2008. Seluk Beluk Profesi Guru, Bandung: Pribumi Mekar.

Mulyasa, 2009. Standar Kompetensi dan Setifikasi Guru.Bandung: Remaja Rosdakarya.

Ngroho, Bambang, 2008. Alat komunikasi, klaten: Sahabat.

Nizar, Samsul, 2002. Filsafat Pendidikan Islam. Jakarta: Ciputat Pers.

Riyanto, Yatim, 2010. Metodelogi penelitian pendidikan, Surabaya: SIC.

Rusli.2009. Teknologi Komunikasi dan Informasi dalam Pendidikan. Jakarta:Gaung Persada

Sardiman, 2011, Interaksi Motivasi Belajar Mengajar, Jakarta :Rajawali Pers

Slameto, 2010. Belajar dan Faktor-Faktor yang Mempengaruhinya, Jakarta: Rineka cipta .

Sudijono, Anas, 2012. Pengantar statistik pendidikan, Jakarta: Rajagrafindo Persada.

Sugiyono.2013. Penelitian Pendidikan. Bandung : Alfabeta.

Suprihatin, Yuni, 2013. Kemampuan Menulis Deskripsi, Bogor: STKIP Muhammadiyah.

Sulfemi, Wahyu Bagja. (2014). Pengaruh Motivasi dan Lingkungan Sekolah Terhadap Prestasi Belajar Sejarah Di SMA Negeri Leuwilang Kabupaten Bogor. Fascho : Kajian Pendidikan dan Sosial Kemasyarakatan 9 (2), 42-52.

Arsyad, dan Sulfemi, Wahyu Bagja. (2014). Minat Siswa Tentang Keadministrasian dengan Hasil Belajar Administrasi Perkantoran. Edutecno. 9 (2), 40-50. 
Badar, Dadan Samsul dan Sulfemi, Wahyu Bagja. (2014). Pengaruh Rasa Percaya Diri dan Motivasi Berprestasi Terhadap Kinerja di Kecamatan Ciampea Kabupaten Bogor. Edutecno. 10 (1), 1-10

Sulfemi, Wahyu Bagja. (2015). Pengaruh Metode Pembelajaran Kontekstual dan Penggunaan Media Video Pendidikan Terhadap Hasil Belajar IPS. Edutecno. $13(2), 1-10$.

Sulfemi, Wahyu Bagja. (2015). Kemampuan Pedagogik Guru. Prosiding Seminar Nasional. STKIP Muhammadiyah Bogor 1. (1).

Sulfemi, Wahyu Bagja. (2015). Challenges Of Indonesian Teacher Competence in dealing with Asean Economic Cummunity (AEC). Engglis Forum. 1 (1), 6979

Syaefudin Sa'ud,Udin 2011, Inovasi Pendidikan, Bandung: Alfabeta.

Syah, Muhibin, 2010. Psikologi Pendidikan, Bandung : Remaja Rosdakarya).

Wibisono, Dermawan. 2013. Panduan Menyusun Skripsi, Tesis dan Desertasi, Yogyakarta: Andi Offset

Widyoko, Eko Putro, 2009. Evaluasi Program Pendidikan, Yogyakarta : Pustaka Pelajar. 